\title{
Livable City One Step Towards Sustainable Development
}

* Dr. Farzaneh Sasanpour ${ }^{1}$

1 Department of Geography and Urban Planning, Kharazmi University, Tehran, Iran

E mail: f.sasanpour@gmail.com

\begin{tabular}{l} 
A R T I C L E I N F O: \\
\hline Article history: \\
Received 2 August 2017 \\
Accepted 15 August 2017 \\
Available online 12 October \\
2017 \\
\hline
\end{tabular}

Keywords:

Livable City;

Sustainable

Development; Iran;

Arak

This work is licensed under a Creative Commons Attribution

NonCommercial - NoDerivs 4.0. "CC-BY-NC-ND"

\begin{abstract}
A B S T R A C T
Cities are the engines of economic growth. According to the United Nations, Today the global urban population is expected to reach 3 billion to 5 billion (61 percent) by 2030.The industrial revolution and the resulting economic-social changes led to the transformation of residential patterns and living patterns. Due to the increasing development of cities and its problems, the theory of sustainable development followed by the approach of the livable city was considered. Livable city environment with good planning is an attractive and safe environment for life, work and development, including good governance, competitive economy, high quality of life and environmental sustainability. The results indicate that the social, economic and environmental aspects of livability of the city of Arak are moderate and unfavorable. Also, the results of the Topsis model, which is a multi-criteria and decision-making model, show that in the environmental dimension of the region two with a score of 0.6859 and in the social dimension of the region of three with a score of 0.92 and in the economic dimension of the region three with a score of 1 , the highest rank Have won. As a result, the city of Arak ranked 58th, is not livable and of the three city areas, zone 3 is closer to the surface of livable. And this process will not be in the path of sustainable development.
\end{abstract}

JOURNAL OF CONTEMPORARY URBAN AFFAIRS (2017) 1(3), 13-17.

https://doi.org/10.25034/ijcua.2018.3673

www.ijcua.com

Copyright (C) 2017 Journal Of Contemporary Urban Affairs. All rights reserved.

\section{Introduction}

The cities can be recognized by scientific systems based on different views and theories. Among the new theories, is livable city, It is a term that describes a comfortable and sustainable environment and urban space as a place to live, work, visit for various aspects of the physical (urban facilities, infrastructure, spatial planning, etc.), as well as non-physical (relationships) Social, economic activities, etc. (Sasanpour et al. 2015). Until recently, initiatives to enhance livability and sustainability have been largely community-based, responding to issues of local concern (Miller, et al., 2013). Livability and sustainability are popular concepts for urban planning and general public discourse, largely because they are representative of values, priorities, and behaviors to which many people and institutions subscribe. It is widely assumed that consumers should have a right to both livable and sustainable communities, which raises questions for planners and decision makers about how to satisfy the needs and desires of current and future residents. Yet, the conceptual linkages between livability and its counterpart

\footnotetext{
*Corresponding Author:

Department of Geography and Urban Planning, Kharazmi

University, Tehran, Iran

E-mail address: f.sasanpour@gmail.com
} 
sustainability are not fully understood, limiting agreement on the policies to promote these ideals and their assessment (Portney, 2013; Van Kamp et al., 2003). Livability, by contrast, brings a necessary pragmatism to the philosophical visions of sustainability. Livability is about now and here, focused on immediate and tangible conditions and interventions, and therefore interpreted as more achievable (Ruth and Franklin 2013). Understanding how livability sits next to sustainability will help planners bridge the desires of residents in the present moment with longer-term needs associated with a sustainability vision. Once basic needs, such as food, shelter, and security are fulfilled, individuals typically emphasize concern for matters over the short term, including livability preferences (Maslow, 1998; Ruth and Franklin, 2013; Gough, 2015). Although these notable distinctions between sustainability and livability imply competing normative and evaluation principles-and different remedies for their respective inherent concerns, there is an important nexus between the two concepts that may assist in the other's success. Livability interventions represent the incremental steps that collectively increase the potential for longer-term strides toward sustainability. "Livable sustainability" has been discussed elsewhere as the result of accommodating short-term, urgent needs or desires of community within a plan for larger scale, longer-term prospects of sustainability (Allen, 2010; Holden and Scerri 2013)

On the other hand, cities as the most important achievements of humans are places that, according to experts, have attracted the most studies to increase livability and achieve sustainable development. The city is a phenomenon that has evolved in history, the result of culture and spatial effects of playing the basic roles of man in the geographical environment and having various dimensions of the environmental, historical, cultural, political, economic, social, and psychological. Hence, comprehensive understanding of the city is possible by knowing all its dimensions and components. Livability encompasses a range of human needs ranging from food and security to beauty and cultural symbols and a sense of belonging to a community or place (Badland, et al., 2014). The livability of the 1980s was due to the rapid development of urban areas relative to urban centers (in fact, at the same time as sustainable development).
In the meantime, Iranian cities, including the city of Arak, are confronted with issues of concern. The city of Arak, with an area of 5341 hectares, is located linearly along the east-west line. The city is located on the geographical coordinates of 42 and 49 longitude 5 and 34 latitudes on the central plateau of Iran, with an average height of 1755 meters above free sea level. The population of Arak city according to the official census of Iran's Statistics Center in 2016 is 571933. (Statistical Center of Iran in 2016). The expansion of Arak city has caused a lot of changes, and on the other hand, due to the rapid growth and development of the city, its migration and inefficiency, despite its advantages, has many problems in the economic, Social, environmental. Therefore, the purpose of this article this paper is search to study the livability of the city of Arak in three dimensions: economic, social, and environmental; on the other hand, it examines three urban areas and investigates the extent to which the city of Arak is in terms of its livable. It is more elaborate on which dimension is it and which region it is more livable to achieve with the achievement of the level of vitality of the city of Arak to achieve sustainable development of the city. The results of the research show that in general, the city of Arak is in poor condition in terms of its livability. The economic dimension of the city is better than the other two dimensions of livability. Of the three metropolitan areas, zone 3 is closer to the surface of livability.

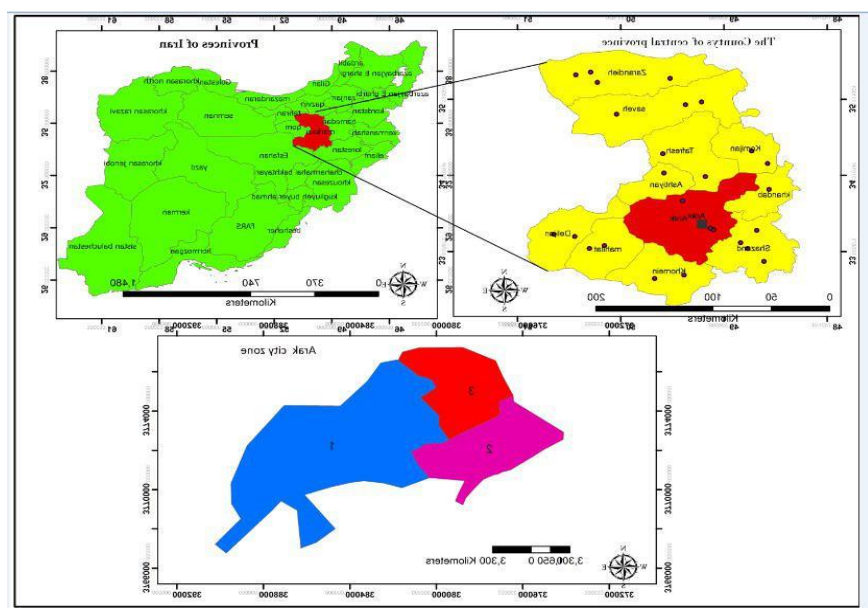

Figure 1. Situation of Arak city in Iran.

\section{Method and Materials}

This research is exploratory of type and is descriptive-analytic of method. The statistical population of the research includes urban authorities, citizens and private sector. The scope of this study is Arak city. To draw maps, ARC GIS software has been used. Information collection 
through: (documentary method) at this stage, by referring to Latin articles and Persian books in the field of research, theoretical foundations are completed. (Field method) This step Includes objective observation, interview and also completion of the questionnaire. The sample size is used by the Cochran formula. In the current research, the population of Arak has 48,412 people. According to the Cochran formula, the sample size required is as follows:

$$
n=\frac{\frac{(1.96)^{2}(0.5)(0.5)}{(0.05)^{2}}}{1+\frac{1}{571933}\left(\frac{(1.96)^{2}(0.8)(0.2)}{(0.05)^{2}}-1\right)}=383
$$

In this research, 14 indicators have been used as the main indicator of the livability of Arak city in three dimensions: social, economic and environmental. Social dimension: public education, leisure, medical and health care considerations, individual and social security, affinity, and partnership, partnership and solidarity. Economic dimension: consumer goods, employment and income, housing, infrastructure and infrastructure services, public transportation. Environmental dimension: Contamination, visual quality, green and clean. Then, Topsis multi-criteria model was used to assess the status of the livability rating of Arak city.
For each dimension, the stages of the topsis model have been calculated. But to avoid prolonging the steps, only the data matrix and then the ranking of the options are given. The steps of the topsis model

1. Data matrix

2. Non-scalable data

3. Non-scalable scaling

4. Determine the positive and negative ideals for each indicator

5. Getting the distance between each option from the positive and negative ideal

6. The relative closeness of each option or the ideal solution

7- Ranking Options

\section{Results}

The study of livability of Arak city was carried out in two stages. First, using the results of the questionnaires and applying the ranking of the Mercer Institute (100-80 highly livable, $80-70=$ Durable, $60-70=$ Acceptable, $50-60=$ poor,$-50=$ non- livable). The results of the research show that Arak city with a rank of 58 is poorly located and is not biodegradable. Then, the research done in relation to livability of Arak's urban areas have been investigated with the Topsis model in three dimensions. Results in economic dimension are as follows. (Table 1)

Table 1. Economic Data Matrix.

\begin{tabular}{llllll}
\hline & $\begin{array}{l}\text { Consumer } \\
\text { Goods }\end{array}$ & $\begin{array}{l}\text { Employment and } \\
\text { income }\end{array}$ & Housing & $\begin{array}{l}\text { Facilities and Public Transportation } \\
\text { infrastructure } \\
\text { services }\end{array}$ & and \\
\hline $\mathbf{1}$ & 31.5 & 25.89 & 8.28 & 11 & 34903 \\
\hline $\mathbf{2}$ & 33.1 & 23.73 & 22.5 & 10.77 & 36325 \\
\hline $\mathbf{3}$ & 35.4 & 48.03 & 67.04 & 41.86 & 31272 \\
\hline
\end{tabular}

After completing the steps of the TOPSIS model, according to the $\mathrm{CL}$ values, the ranking of economic options can be made, so that the more livable is area 3 then the 2 and 1 .
Ranking Options $A_{3}>A_{2}>A_{1}$ The social dimension table was formed and social dimension indicators were also examined with the Topsis model (Table 2)

Table 2. Social Data Matrix.

\begin{tabular}{lllllll}
\hline & $\begin{array}{l}\text { public } \\
\text { education }\end{array}$ & free time & $\begin{array}{l}\text { Medical and } \\
\text { Health Care }\end{array}$ & $\begin{array}{l}\text { Individual and } \\
\text { Social Security }\end{array}$ & $\begin{array}{l}\text { Affinity } \\
\text { Place of Honor }\end{array}$ & $\begin{array}{l}\text { Partnership } \\
\text { and solidarity }\end{array}$ \\
\hline $\mathbf{1}$ & 1.10 & 14.83 & 0.26 & 0.11 & 60 & 65 \\
\hline $\mathbf{2}$ & 9.25 & 1.93 & 0.10 & 0.05 & 65 & 70 \\
\hline $\mathbf{3}$ & 4.21 & 9.49 & 1.40 & 3.02 & 50 & 50 \\
\hline
\end{tabular}

After completing the steps of the TOPSIS model, according to the $\mathrm{CL}$ values, the ranking of social options can be made, so that the more livable area 3 is then 1 and 2 .

Ranking Options $A_{3}>A_{1}>A_{2}$
The environmental dimension indicators for calculating the livability of Arak urban areas are specified in the table below (Table 3). 
Table 3. Environmental Data Matrix. Pollution

Visual quality

\begin{tabular}{l|lll}
$\mathbf{1}$ & 0.53 & 129.79 & 30.86 \\
$\mathbf{2}$ & 21.16 & 35.52 & 16.28 \\
$\mathbf{3}$ & 21.18 & 114.83 & 15.06
\end{tabular}

After calculating the environmental dimension indices in the Topsis model, the results show that region 2 is more livable then 3 and 1

Ranking Options $A_{2}>A_{3}>A_{1}$

\section{Discussion and conclusions}

As it was said, livable cities are places where social life is communicated along with relationship. These cities are concerned with the creation of architecture, the street landscape and the design of public spaces, which facilitates the presence of city residents in the public domain and in the heart of the city. Such cities are committed to reducing traffic and solving safety, pollution and noise through a set of mechanisms (Lenard, 1997, 3).

The study of Arak city's livability in three dimensions of economic, social and environmental characteristics shows that this city has more livable environmental indicators of the economic dimension, but it is seen in the very poor environment of non-habitat. Total in three dimensions in Arak has a poorly-hit 58th place in the Mercer ranking. These studies were also studied in three areas of the city of Arak. The model used was a multi-criteria Topsis model. Also, the results of the Topsis model, which is a multi-criteria and decision-making model, show that in the environmental dimension of the region two with a score of 0.6859 and in the social dimension of the region of three with a score of 0.92 and in the economic dimension of the region three with a score of 1 , the highest ranks have won. As a result, the city of Arak ranked 58th, is not livable. This study shows that the urban areas of Arak are not at the appropriate level of survival, but the 3rd district in other parts of the city has a better livable status. On the other hand, livability is a way to achieve sustainable development, but the results of the research show that Arak is not only livable, but is far from sustainable development.

Conclusions

Livability is a broad term consisting of four main elements: the pride of society, the desire to work, jobs and workgroups, human development and regional solutions, and empowerment of society. Livability becomes reality. If citizens accept the responsibility actively, this is the key to initiating change. The study of Arak city in 14 indicators and three dimensions of livability shows that this city is not only non-livable, but it has not been able to make environmentally clean, economically efficient, and occupationally urban and socially sense of belonging to location and identity To create citizens in Arak. Therefore, it is far from sustainable development, and it seems that to reduce this gap and increase the livability, these should be done: increasing social awareness, increasing popular participation, empowerment, reducing pollution, increasing green space, increasing employment and income. And with increasing the level of livability, a step towards sustainable development of the city of Arak could be taken.

\section{Acknowledgement}

This research did not receive any specific grant from funding agencies in the public, commercial, or not-for-profit sectors.

\section{References}

Allen, T. F. H. (2010). "Making Livable Sustainable Systems Unremarkable." Systems Research and Behavioral Science, 27 (5), 469-79.

Badland, H. Whitzman, C., Aye, L., Butterworth, H. (2014) Urban Liveability: Emerging Lesson from Australian for exploring the potential for indicators to measure the social determinants of health. Social Science and Medicine, (111), 64-73.

Gough, M. Z. (2015). Reconciling Livability and Sustainability: Conceptual and Practical Implications for Planning. Journal of Planning Education and Research, 35(2), 145-160.

Holden, M., and Scerri, A. (2013). "More Than This: Liveable Melbourne Meets Liveable Vancouver." Cities, 31, 444-53.

Lennard, H. L. (1997)."Principles for the Livable City" In Lennard, S.H., S Von UngernSternberg, H.L.Lennard (Eds), Making Cities Livable. International Making Cities LivableConferences. California, Usa: Gondolier Press.

Maslow, A. H. (1998). Toward a Psychology of Being, $3^{\text {rd }}$ edition. New York: John Wiley.

Miller, H. J., Witlox, F., and Tribby, C. P. (2013). Developing Context-Sensitive Livability Indicators for Transportation Planning: A Measurement Framework." Journal of Transport Geography 26, 51-64.

Portney, K. (2013). Taking Sustainable Cities Seriously: Economic Development, the 
Environment, and Quality of Life in American Cities. Cambridge: MIT Press.

Ruth, M., and Franklin, R. S. (2013). Livability for All? Conceptual Limits and Practical Implications. Applied Geography 49, 18-23. Sasanpour, F., Simin, T., Hamza, J.A. (2015), Measuring and assessing urban livability in twenty-two regions of Tehran metropolitan area. Regional Planning Quarterly, 18, 42-27.
Statistical Center of Iran. (2016). Arak Population Census.

Van Kamp, I., Leidelmeijer, K., Marsman, G., and de Hollander, A.(2003). Urban Environmental Quality and Human WellBeing. Landscape and Urban Planning, 65 (2), 5-18. 